\title{
Unity and diversity of the kite phenomenon: a comparative study between Jordan, Armenia and Kazakhstan
}

Desert kites are found across a vast region. This paper presents a detailed description of kites from the Harrat al-Shaam region (Jordan) and proposes a comparative study, as well as an analysis of the morphology and organisation of kites known from Mount Aragats (Armenia) and the Ustyurt Plateau (Kazakhstan). A complete inventory of the structures in each region highlights their architectural characteristics and their spatial distribution in the landscape. Some preliminary results were obtained by comparing both regions: the core area in eastern Jordan, and peripheries - sometimes very distant - such as in the Caucasus and Central Asia. Chronological data were also compared, when available. All these different and complementary aspects were finally combined with satellite imagery analyses. The interactive process between satellite images and fieldwork observations has enriched both approaches, while yielding preliminary key elements of interpretation for a better understanding of the kite phenomenon on a global scale.

Keywords: desert kites, GIS, Jordan, Kazakhstan, Armenia, typology, landscape archaeology

\author{
Olivier Barge ${ }^{1}$, Jacques Élie \\ Brochier $^{2}$, Emmanuelle \\ Régagnon ${ }^{1}$, Marie-Laure \\ Chambrade $^{1}$, Rémy Crassard ${ }^{1}$ \\ ${ }^{1}$ CNRS, UMR 5133 Archéorient, \\ Maison de l'Orient et de la \\ Méditerranée, 7 rue Raulin, \\ 69007, Lyon, France \\ ${ }^{2}$ Aix-Marseille Université \\ (AMU), CNRS, UMR 7269 \\ LAMPEA, Maison \\ Méditerranéenne des Sciences de \\ l'Homme, 5 rue du Château de \\ l'Horloge, BP 647, 13094, \\ Aix-en-Provence, France \\ e-mails: olivier.barge@mom.fr; \\ jacques.brochier@univ-amu.fr; \\ emmanuelle.regagnon@mom.fr; \\ marie.chambrade@gmail.com; \\ remy.crassard@mom.fr
}

\section{Introduction, regional setting and methodology}

The known area of distribution of kites is very large, from Arabia and the Near East, to Armenia in the Caucasus and the Aralo-Caspian region, namely south-western Kazakhstan and western Uzbekistan (e.g. Barge et al. 2013). The kite structures, typologically well known for decades and often interpreted as giant hunting traps or game drives, are being reappraised by means of a research project called Globalkites (Crassard et al. 2014; see www.globalkites.fr for a regularly updated interactive distribution map). These structures, comprising long driving walls or stone alignments (antennae) converging towards an enclosure surrounded by small closed rooms (cells), are being stud- ied through different approaches, including archaeology and geomatics, geoarchaeology, environmental studies, zooarchaeology and animal ethology (e.g. Barge, Brochier \& Crassard, this volume 2015; Chahoud, Vila \& Crassard, this volume 2015). The main questions regarding the kites' expansion focus on their function(s) and how they worked, on their dating and on the reason(s) why such a wide distribution occurred through time.

With the aim of answering these questions, and amid the various studies carried out, the analysis of kite morphology through high-resolution satellite images has revealed a great diversity that can be ordered spatially (Barge, Brochier \& Crassard, this volume 2015). Initial 
analyses show a marked regionalism with many characteristic features. Some sectors of the area of distribution group together sets of kites with common characteristics.

This approach completes field enquiries, allowing us to tackle the issues of function and chronology, but fieldwork, with the exception of the Negev 'kites' (Holzer et al. 2010; Nadel et al. 2013), has yielded little data on the function of kites. Dates generally also appear rough and approximate. Moreover, the representativeness of works on the scale of the Middle Eastern and Central Asian distribution area remains low, simply because the number of studies specifically focusing on kites differs notably from one field to the other, and the archaeological literature provides very little factual and descriptive data, making comparisons difficult.

Two regions were already the focus of fieldwork (Armenia and Kazakhstan), in the framework of the Globalkites project (Brochier et al. 2014; Barge, Brochier \& Karakhanyan 2015; Barge et al., in press). In Jordan, following a preliminary visit and before imminent field exploration, work concentrated initially on the fine observation of satellite images. Each of the regions under study was dealt with using the same method, allowing the comparison of collected data. In each case, a 'window' was defined and all kites within the window, including those studied in the field, had their characteristic features measured and described from the satellite images, before being recorded within a Geographic Information System (GIS; Barge, Brochier \& Crassard, this volume 2015). This approach had the advantage of allowing work on different scales and enabling an assessment of the representativeness of cases studied within the window as a whole.

Following this process, inter-regional comparisons can be made. The principle of convergent walls ending on an enclosure was observed elsewhere (North Africa, Scandinavia, North and South America, etc.), both on land and in aquatic environments (e.g. Payne-Gallwey 1886; Custred 1979; Ingold 1980; Riemer 2009; Benedict 2011; Storemyr 2011; Brink 2013). The presence of cells being both contiguous to the enclosure and outside it, however, has only been documented in the area between the Ustyurt Plateau and Central Arabia. This specificity leads to consider these structures as part of a single phenomenon initially identified in the Harrat al-Shaam, even if a wide range of size and shape diversities is noticeable. Another element indicating a certain unity to this phenomenon is the fact that each of the twenty-four characteristic features in our database can be fed for each kite, whatever the studied area. In this article we will draw a comparison of the kites of the Harrat al-Shaam window (in eastern Jordan) mainly from preliminary interpretations obtained through the observation of satellite images - with two other regions where fieldwork has been carried out (Armenia and Kazakhstan).

The Harrat al-Shaam kites are of particular interest in that they are very densely distributed across the landscape, and because of the very ancient dates proposed for many of them (Helms \& Betts 1987; Akkermans, Huigens \& Brüning 2014) and the large number of studies they motivated after their discovery. Moreover, they are positioned in the middle of the kite distribution zone, while those of

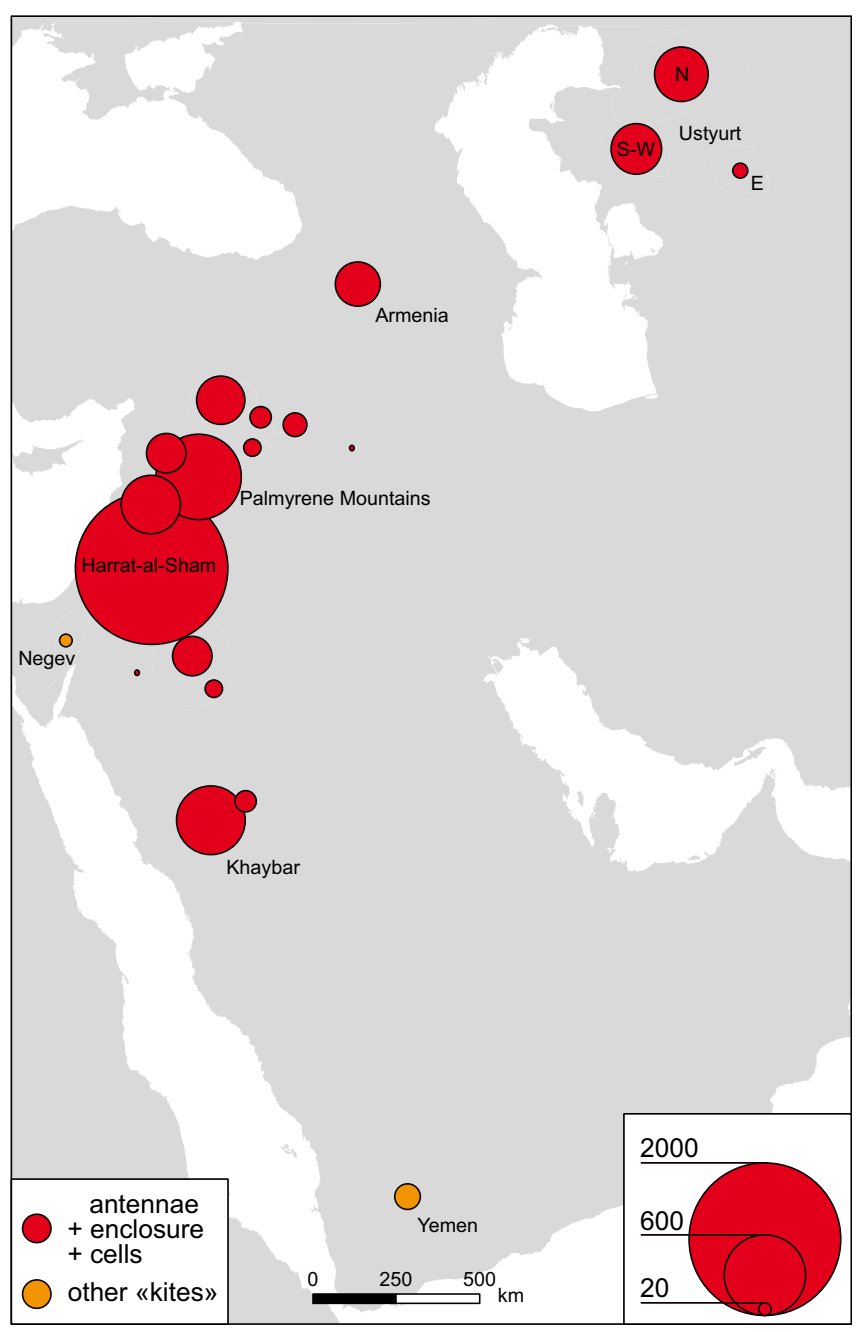

Fig. 1.

Number of kites of the main regions in the distribution area; regions were empirically outlined through observed morphology. On the Ustyurt Plateau, the 'S-W' circle corresponds to kites located near the southwestern Chink, and the ' $\mathrm{N}$ ' circle includes, among others, doublearrowed kites. 


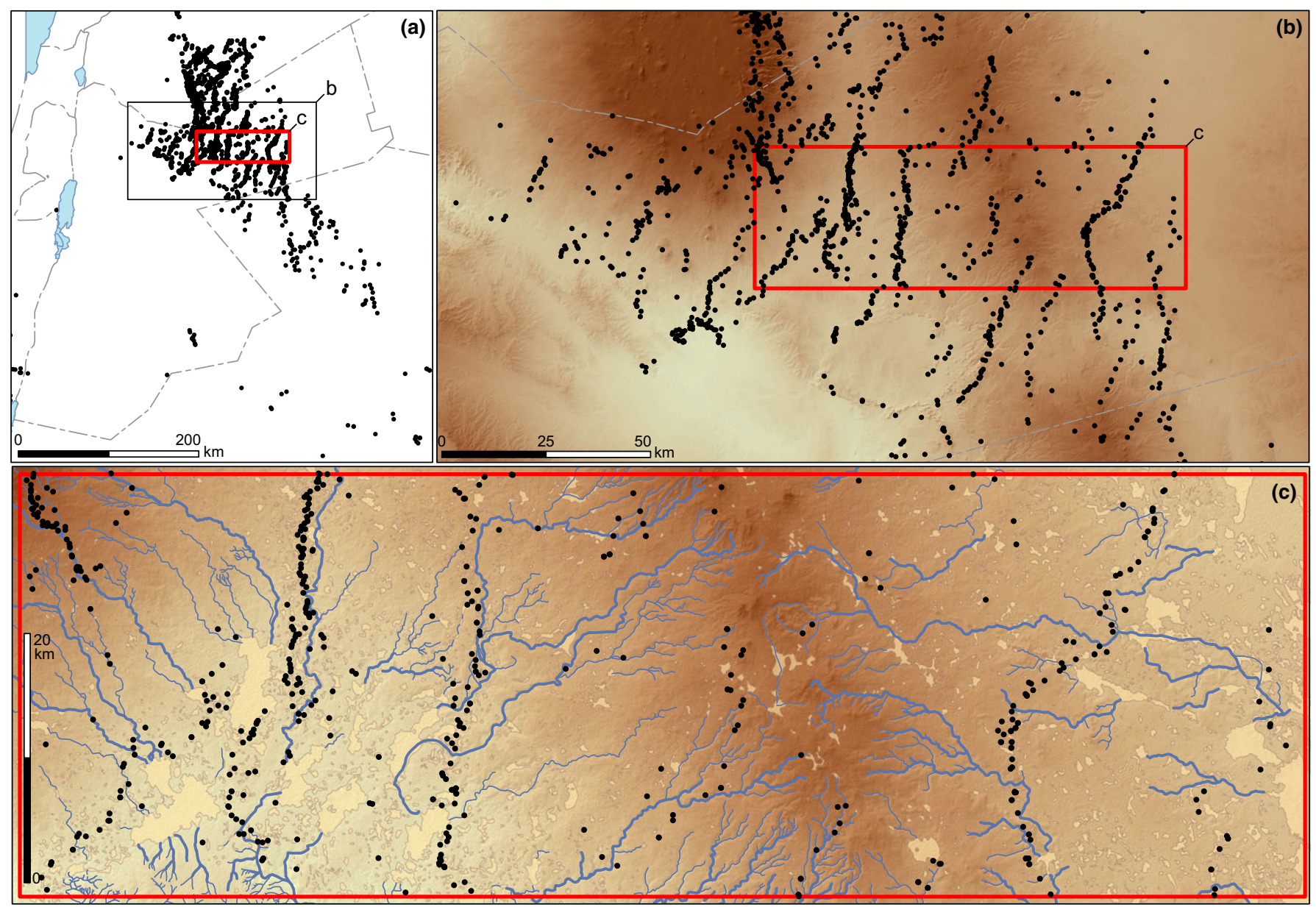

Fig. 2.

Insertion of the window of study to the north-east of Jordan: a transect in the kite chains of the Harrat al-Shaam.

Armenia and Kazakhstan are located on the northern margins (Fig. 1).

A rectangular window of $100 \times 35 \mathrm{~km}$ (i.e. $3500 \mathrm{~km}^{2}$ ), which includes a total of 530 kites, was defined according to a west-east transect in the very heart of the Jordanian Harrat al-Shaam (Fig. 2). These kites are currently being studied by means of satellite images and a GIS conceived along the same lines as those of the Armenian and Kazakh windows, enabling the provision of information for twenty-four descriptors (Brochier et al. 2014). In addition, this GIS was made more elaborate with the complete vectorisation of the architectural elements making up the kites, to which one should add walls of the 'meander' type (Kempe \& Al-Malabeh 2013), and certain environmental elements (hydrographical network, Digital Elevation Model). The enclosures and cells were also systematically described. Moreover, seventeen kites were explored in
2013, enabling preliminary observations prior to excavations, which are planned for the near future, in April 2015.

After a presentation of the data known for the Harrat al-Shaam kites as well as newly gathered information, a comparison with the Mount Aragats region in Armenia and the Ustyurt Plateau in Kazakhstan is suggested. Comparisons between the three regions, from the perspective of insertion in the landscape, of morphological characteristics and architectural details, will lead to a more general discussion as regards function, chronology, socio-economic aspects and spatial distribution of kites.

\section{The kites from the Harrat al-Shaam}

\section{Location and integration in the landscape}

The Harrat al-Shaam is a basaltic plateau sprawling from southern Syria through north-eastern Jordan, to northern 
Saudi Arabia. With more than 2000 structures recorded, the Harrat al-Shaam contains almost half the kites listed so far (total in the global zone of distribution: more than 5000). The most important concentration is found in the Syro-Jordanian sector where they were first discovered. The latter were the subject of many studies (e.g. Betts \& Helms 1986; Helms \& Betts 1987; Échallier \& Braemer 1995; Betts 1998; Kempe \& Al-Malabeh 2013). In the Jordanian portion of the Harrat al-Shaam only, there are more than 1000 kites and their distribution is not random, as it corresponds to several criteria (Helms \& Betts 1987; Kempe \& Al-Malabeh 2013), which are debated in certain cases, such as in southern Syria (Échallier \& Braemer 1995).

First of all, looking at the entire Harrat al-Shaam (Fig. 2/b) as a whole, analysis of the images shows kites distributed along lines. These alignments show a northeastern-south-western orientation, and they extend over a distance of between $c .15$ and $60 \mathrm{~km}$. They are located at a distance of approximately $15 \mathrm{~km}$ from each other, with the exception of a zone centred on a basaltic massif reaching an elevation of $1000 \mathrm{~m}$, the latter actually being the line dividing the headwaters of the region's hydrographical network (Fig. 2/c). These alignments are at times so dense that the kites connect to each other through antennae. It is thus possible to speak of chains of kites (Betts 1982). Kempe and Al-Malabeh (2013) were able to count nine of them. The list has since grown, enabling one to distinguish about twelve chains. The exact number of chains and alignments, however, is a subject of contention since the number can vary according to the conception one has of these chains (connections between kites, minimal number of kites accounted for in the alignment).

According to Kempe and Al-Malabeh $(2012,2013)$, the orientation of kite openings over the entire Harrat al-Shaam is towards the east, the south-east and the south, apart from very rare exceptions (around 2\%). In the window studied, the great majority of kites open towards the east, with a mean orientation of $95.6^{\circ} \mathrm{N}(95 \%$ confidence interval: $92.7^{\circ} \mathrm{N}-98.4^{\circ} \mathrm{N}$ ); a few minor cases are oriented in other directions (Fig. 3). The orientations of chains and kite openings would therefore follow a quite homogeneous pattern for the region as a whole.

On the window scale, several aspects related to insertion in the landscape are noteworthy. In $85 \%$ of cases a more or less marked break appears in the slope at the enclosure's entrance. The enclosure is either placed downhill from the antennae's end or on a higher location (on a ledge at the top of a slope). Moreover, $56 \%$ of kites are located near wadis (Fig. 4/b) or mudflats ( $q a^{\prime} a$ in Arabic; Fig. 4/c), which become water points and grazing grounds during humid periods. Configurations vary but frequently antennae open onto one of these, and sometimes were probably built in order to include them within the area they covered. Several chains are partly constructed along a watercourse. This is clearly the case of the Wadi Safawi chain (Fig. 4/a), which gives it an unusual north-western-south-eastern orientation. In this case,
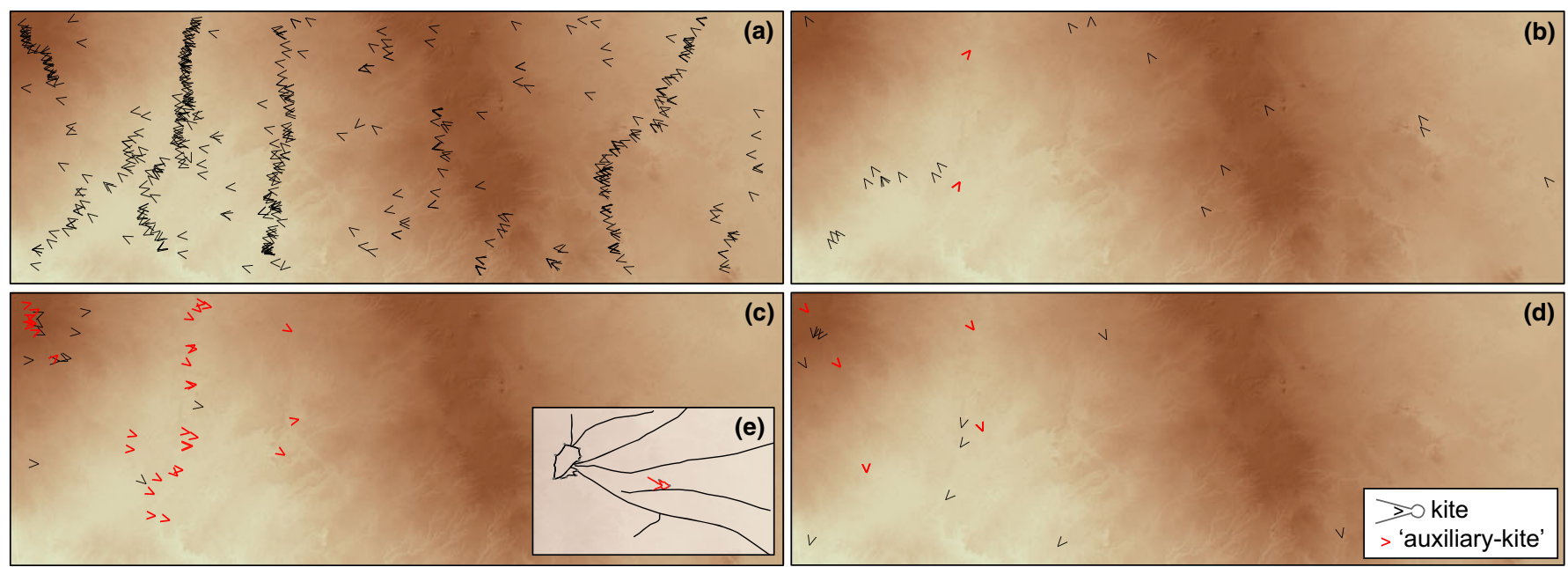

Fig. 3.

Orientation of the kites: a. open to the east; b. open to the south; c. open to the west; d. open to the north; e. an example of auxiliary kites. The great majority of the kites are open towards the east. Those oriented in another direction include the specific case of auxiliary kites that only exist to the west of the window of study. 


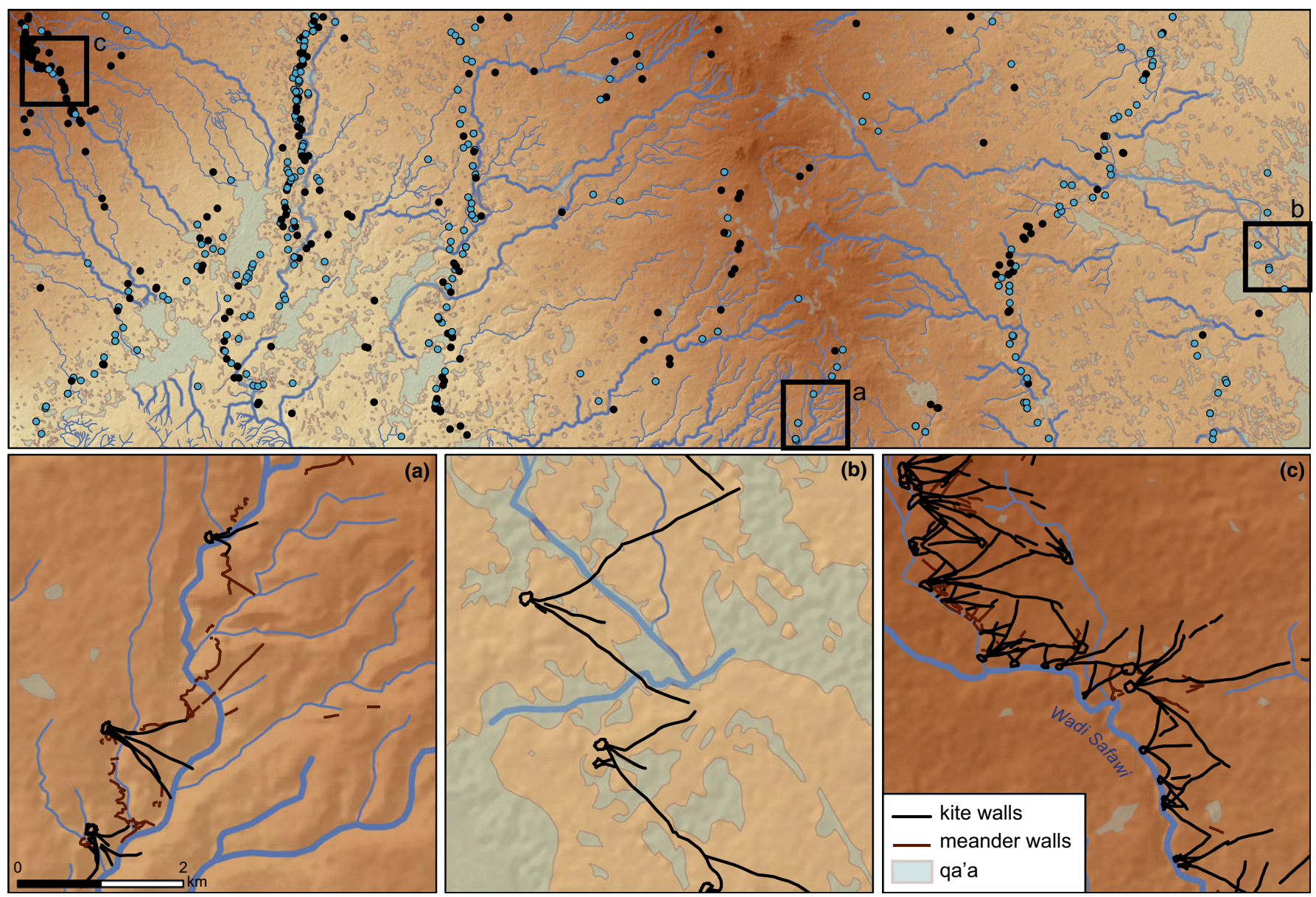

Fig. 4 .

The location of kites and hydrographical network; the blue dots represent kites the antennae of which frame a wadi or a $q a$ ' $a$ (the $q a^{\prime} a$ taken into account are over 2 ha).

the kite/wadi position is inverted and the kites are sometimes absent near mudflats and large wadis. So far our data do not seem to confirm any link between kites and water resources (Fig. 4).

\section{Morphology of the kites}

The antennae of kites in the Harrat al-Shaam window, preliminarily observed in the field in 2013, are walls with a simple facing. The latter are low and generally preserved over only one course. The median number of antennae per kite is two, and more than $44 \%$ of kites in the window have more than two antennae. Frequently an antenna is located on the bisecting line between the two main antennae, without any connection to the enclosure; this configuration occurs sufficiently often to suggest a functional explanation for this third antenna. The maximum number of antennae is eight, but one should note that this high number is related to cases where several generations of kites have been superimposed (see below, 'Chronology'). The antennae are of substantial length, with a median of $497 \mathrm{~m}$, and can be several kilometres long (max. length = $4.7 \mathrm{~km}$ ). In $50 \%$ of cases (inter-quartile range), their length lies between 252 and $928 \mathrm{~m}$.

The enclosure walls are sometimes preserved over two courses but are barely higher than those of the antennae. The shapes of enclosures show much diversity (from circular to star-shaped, with several variants in between), and their entrance is only rarely funnel-shaped $(13 \%$ in the window). The median surface of the enclosure is 0.99 ha.

The enclosures are surrounded by cells, the number of which can reach twenty or more. If these are quite exceptional occurrences, it is not infrequent that the number of kite cells of the Harrat al-Shaam window reaches ten, and the median is six. These cells are circular $(86 \%$, Fig. $5 / \mathrm{d}$, 


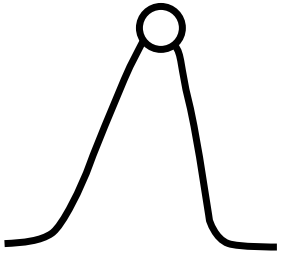

point

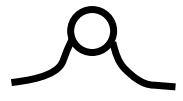

nascent-point

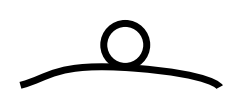

tangent
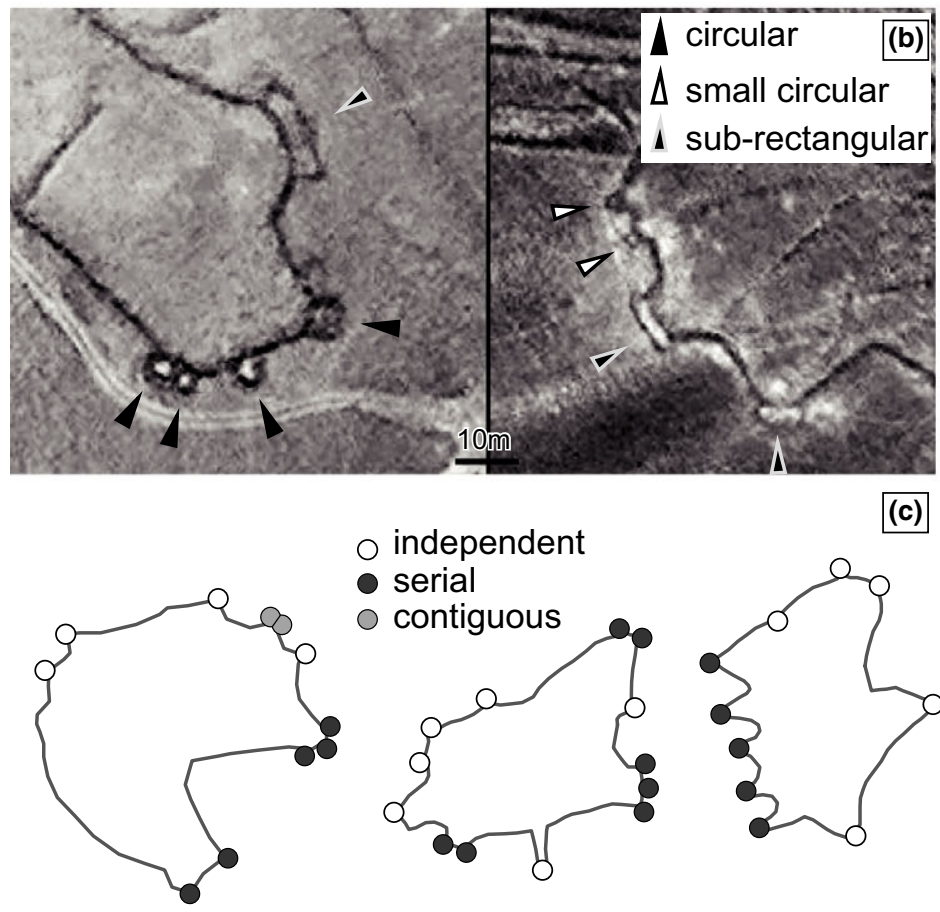

○ independent

- serial

○ contiguous

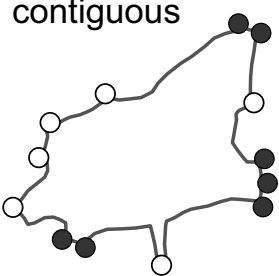

(c)

(a)
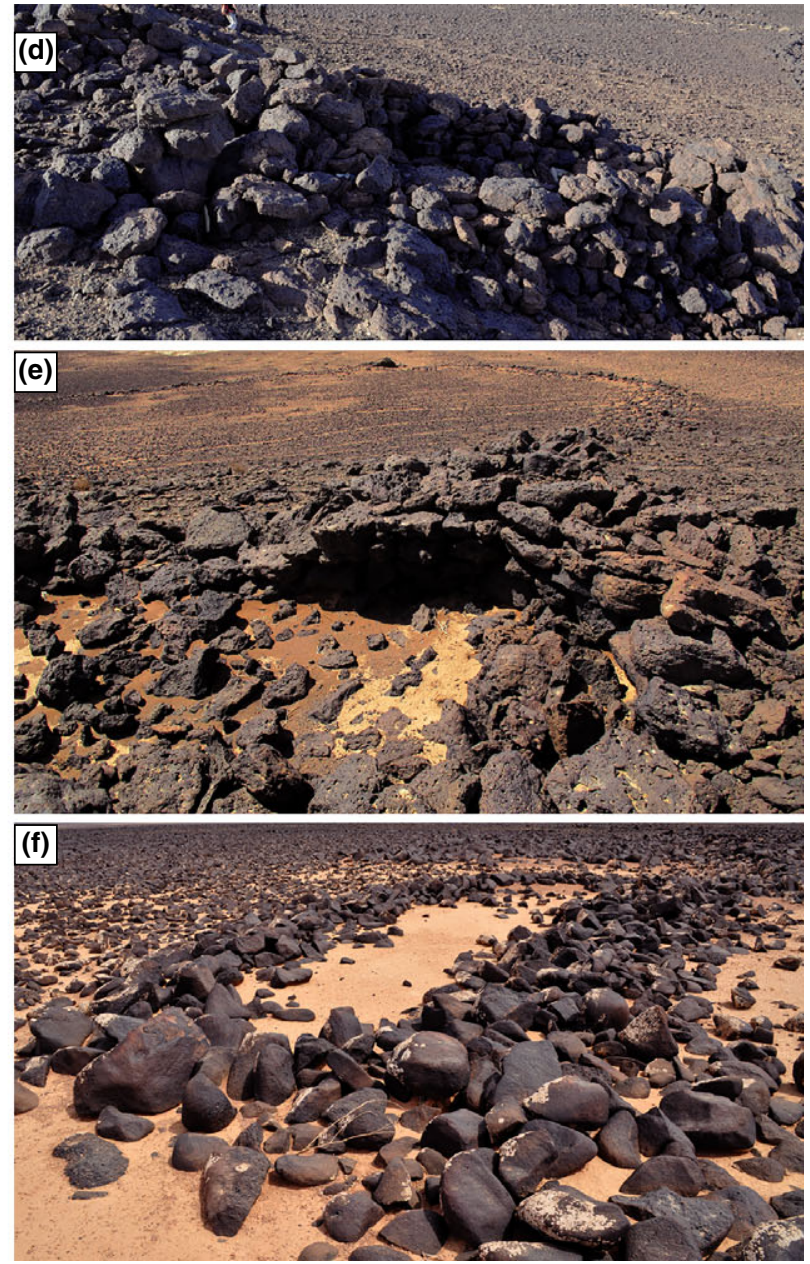

Fig. 5 .

Left: descriptions of cells from the observation of satellite images; a. location with respect to the enclosure; b. shape; c. relation between the cells. Right: the position of the lower floor of the cell in comparison to that of the enclosure (seen during field trips); d. lower elevation cell in comparison to the enclosure's elevation, making use of topography; e. higher elevation cell in comparison to the enclosure's elevation (one can make out the enclosure's contour downhill, on the slope); f. the same elevation cell in comparison with the enclosure's elevation, here in the case of a sub-rectangular cell.

e), and less often sub-rectangular (12\%, Fig. 5/f). Satellite images also show very tiny cells that appear to be circular (small circular, Fig. 5/b); they were counted separately (11\%). Finally, $1.5 \%$ of the total number comprises shapes that could not be determined. The cells are located in different ways in relation to the enclosure (Fig. 5/a). They can be placed at the extremity of an external pointed appendage (39\% of cells are of a pointed type, and among these, $85 \%$ are circular, $7.5 \%$ are sub-rectangular and $6.5 \%$ are small cells). These appendices can be very large, altering the enclosure's general shape until they form some kind of corridor. In this case the point is most often very short (less than $12 \mathrm{~m}$ ) and is referred to as a 'nascent point'; this is the most frequent linkage to the enclosure, since it accounts for $44 \%$ of cases. Other types of attach- ment to the enclosure are found, but these are less frequent: in $14 \%$ of cases, the cell is simply on a tangent to the enclosure wall, $1.5 \%$ of cells are recessed in relation to the enclosure wall, and $0.5 \%$ are located within the enclosure. Most of the cells are independent (76\%), but some work as a series of several cells, at times contiguous $(10.5 \%$ of the total number) (Fig. 5/c). The cells' average surfaces, which were provisionally calculated from a sub-sample (consisting of the explored cells, i.e. 154 out of the 3031 registered), are $13 \mathrm{~m}^{2}$ for circular cells and $30 \mathrm{~m}^{2}$ in the case of sub-rectangular cells.

The special cases: 'auxiliary kites', 'bag-like' kites, abandoned projects and 'meander walls'

Kites oriented towards the west are for the most part connected via antennae to a kite of larger span, open towards 
the east (Fig. 3/e). Dubbed 'auxiliary kites' (Kempe \& Al-Malabeh 2013), these kites are characterised by an enclosure, the average surface of which is very reduced (mean of 0.15 ha) with most often, on the side, very few cells (2.9 on average). They are all located in the western half of the window of study (Fig. 3/c). A hypothesis was put forward that these were anti-retreating devices (Échallier \& Braemer 1995) facilitating the culling of animals that were attempting to escape in the opposite direction to the main large kite's opening, thus maximising the hunt or gathering of animals.

Kempe and Al-Malabeh (2013) make a passing mention of kites, the construction of which would have been abandoned. Fifty-two cases were recorded within the Jordanian Harrat al-Shaam window of study (Fig. 6). A more detailed observation of the different construction stages of kites on images quite clearly recalls the evolution and stages of building with the passage of time (see below, 'Chronology'). Many kites, which remained incomplete, comprise only enclosure walls whose line was interrupted by spaces probably meant for cells (Fig. 9/c). Other kites have enclosure walls and antennae projections, sometimes prolonged by dotted lines. Finally, the most advanced incomplete projects include enclosure walls, antennae projections and some already built cells. These kite projects are either isolated or located within chains. As in the latter case, the kite's location was either permanently abandoned or reused after the construction of a superimposed kite, or was built right next to the former one. In this case, the projects are built slightly behind to the west in relation to the chains.

Among enclosure shapes Kempe and Al-Malabeh (2013) noted one type that is particularly striking, the 'bag-like' enclosure. These enclosures are characterised by long antennae, which stay parallel as one gets closer to the enclosure, forming a corridor about 50 to $200 \mathrm{~m}$ long. They have a very wide entrance, measuring over $25 \mathrm{~m}$. The enclosure's shape generally does not include long points and the outline resembles that of a cauliflower. This relationship between the width of the entrance and the absence of points can be further clarified by mapping the kites with an entrance wider than $25 \mathrm{~m}$; significantly, $80 \%$ of them do not show a proximal point (Fig. 7).

Finally, and as Kempe and Al-Malabeh (2013) have pointed out, one cannot talk about kite alignments without mentioning the 'meander walls'. The complete vectorisation of the latter in the window of study allows us to observe that they are mostly associated with kite alignments, except for the one furthest to the east. They connect kites with one another, modifying the perception of alignments by increasing the chain aspect (Fig. 8). They are built along kite lines but there are extensions oriented east-west, which therefore associate kites that at first appear isolated. Finally, their function seems most probably related to that of kites, as shown by the presence of cells at the top of some meander walls (Fig. 9/b, centre), or by the existence of long rectilinear walls very similar to those of kite antennae. Distinguishing them from true kites, however, becomes difficult when these walls join up at a dead end, forming a set very similar to bag-like kites but without any visible cell.

There are perhaps elements of relative chronology between kites, meander walls and bag-like kites. Kempe and Al-Malabeh (2013) have, for instance, suggested that the construction of meander walls could predate that of

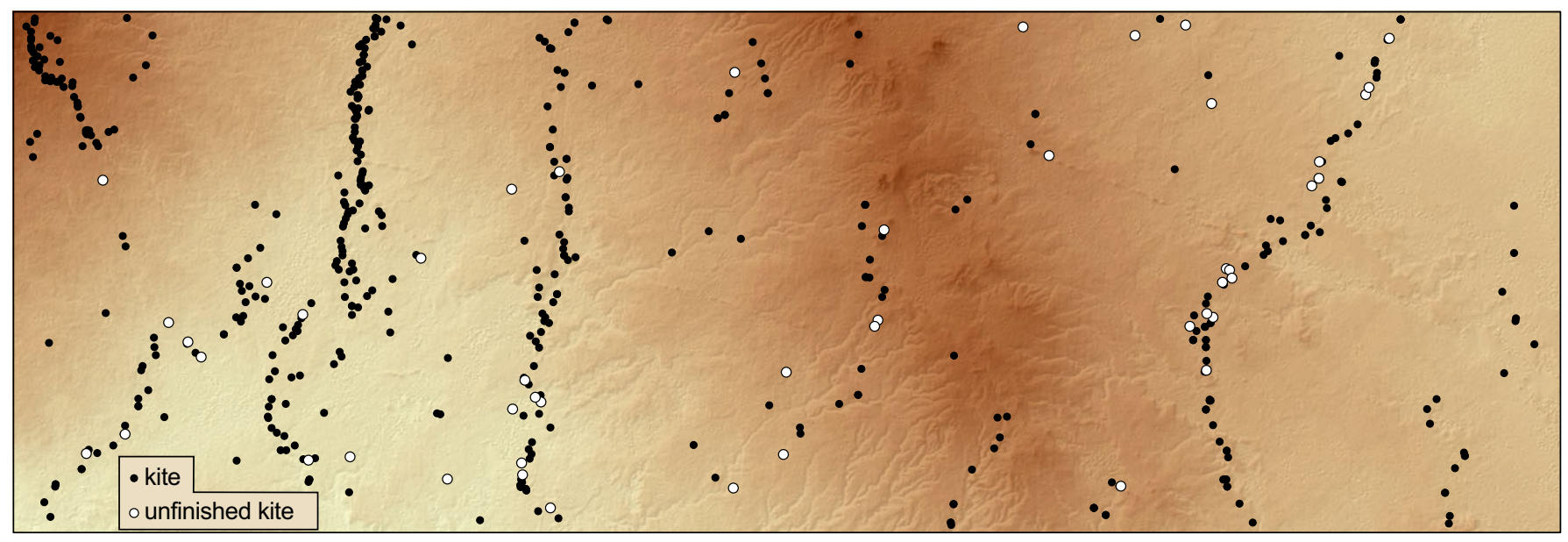

Fig. 6.

Unfinished kites, which are uniformly distributed within the window of study, located both in chains and in isolation. 


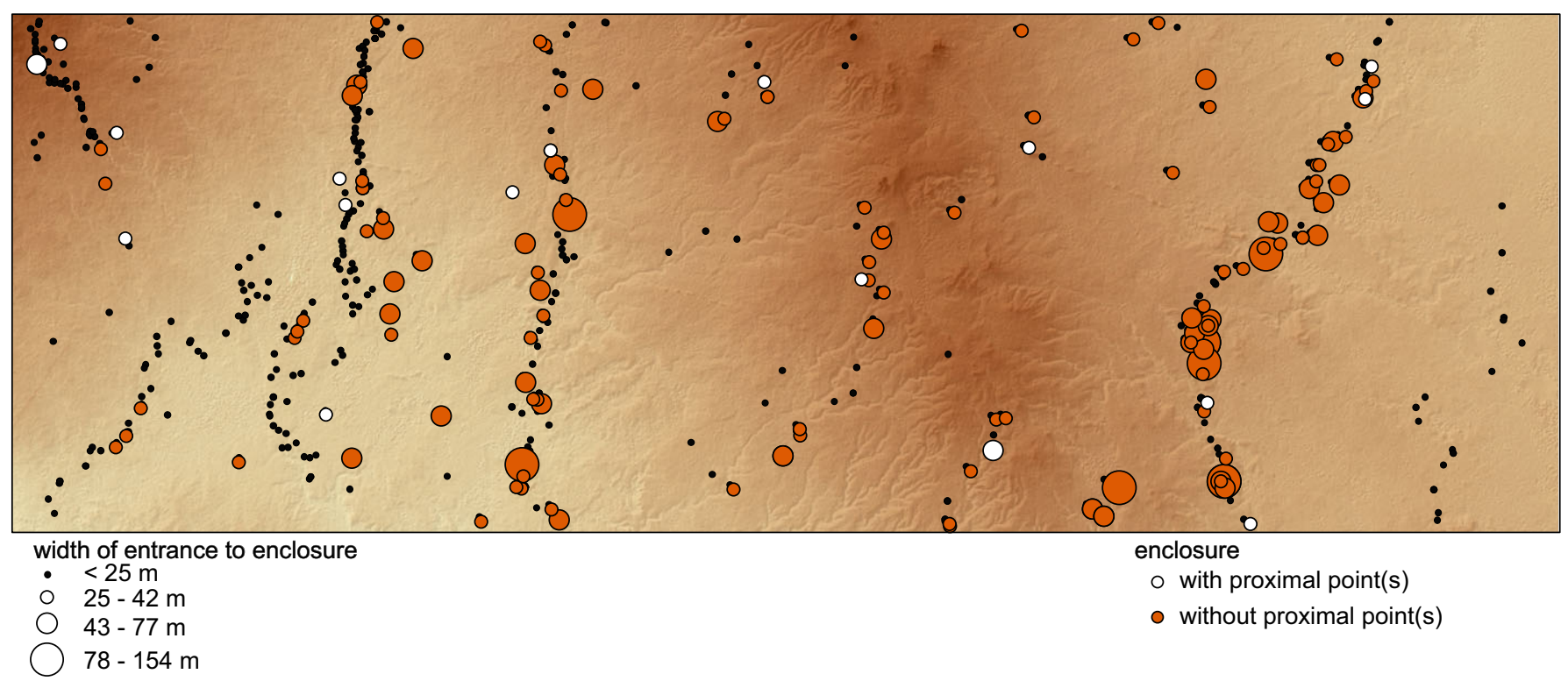

Fig. 7.

White and orange circles showing kites with an entrance larger than $25 \mathrm{~m}$ and the presence/absence of a proximal point.

kites, but the reading of satellite imagery alone does not in our opinion lead to unequivocal observations.

\section{Architectural details}

In ways similar to Armenia's and Kazakhstan's kites, much care was given to the construction of cells. These cells are on a level surface or high above ground. This is a characteristic that was neither always related to their position in relation to the enclosure nor due to their state of preservation. Stones are calibrated and the elevation can reach $1.5 \mathrm{~m}$ over the actual ground surface. Walls are usually constructed of single-facing stone courses with an external abutment, while some examples of important volumes of spoil around the highest walls suggest a possible use of the double-facing construction technique. Kite cells explored appear completely closed.

The Jordanian Harrat al-Shaam cells were placed in three different ways, relative to the enclosure: 1) on the same level surface (Fig. 5/e,f); 2) downhill, hidden by a break in the slope (Fig. 5/d); and 3) in a commanding position, on the slope itself. In the first case, cells could have been partly dug out, as seen in Armenia and on the edge of the Ustyurt Plateau (Brochier et al. 2014; Barge et al., in press) or in southern Jordan (see Abu-Azizeh \& Tarawneh, this volume 2015). This proposal resulted from the observation in the field of a looted cell, the wall of which was visible some $80 \mathrm{~cm}$ below the actual surface.
Otherwise, cells can be built directly_or almost—on the basalt substratum.

The care given to the building of cells and their large number emphasises the fact that they played an important part in the use(s) of kites. Moreover, observations of the varied combinations in morphology, size and position, in relation to the enclosure, and of the relationships between them, suggest that they could have filled distinct and specific functions.

\section{Chronology}

The Jordanian Harrat al-Shaam kites were subjected to multiple rearrangements (Fig. 9). These various transformations are linked to the reorganisation of certain elements of the kite or to the construction of other kites on the same spot. They are frequent and sufficiently visible on satellite images, so as to render possible the definition of the same kite's three successive stages (Fig. 9/a). In addition, nearby there are many and various cases of superimposition or construction of other structures (Fig. 9/b), such as 'jellyfish' constructions (Helms 1981) or 'wheel houses' (Kempe \& Al-Malabeh 2010), encampments, pastoral enclosures, graves, etc.

These instances of rearrangements and superimpositions are numerous $(45 \%)$ when compared to kites that revealed only one stage. The proportion reaches $64 \%$ when including the jumble of antennae. On the scale of global distribu- 

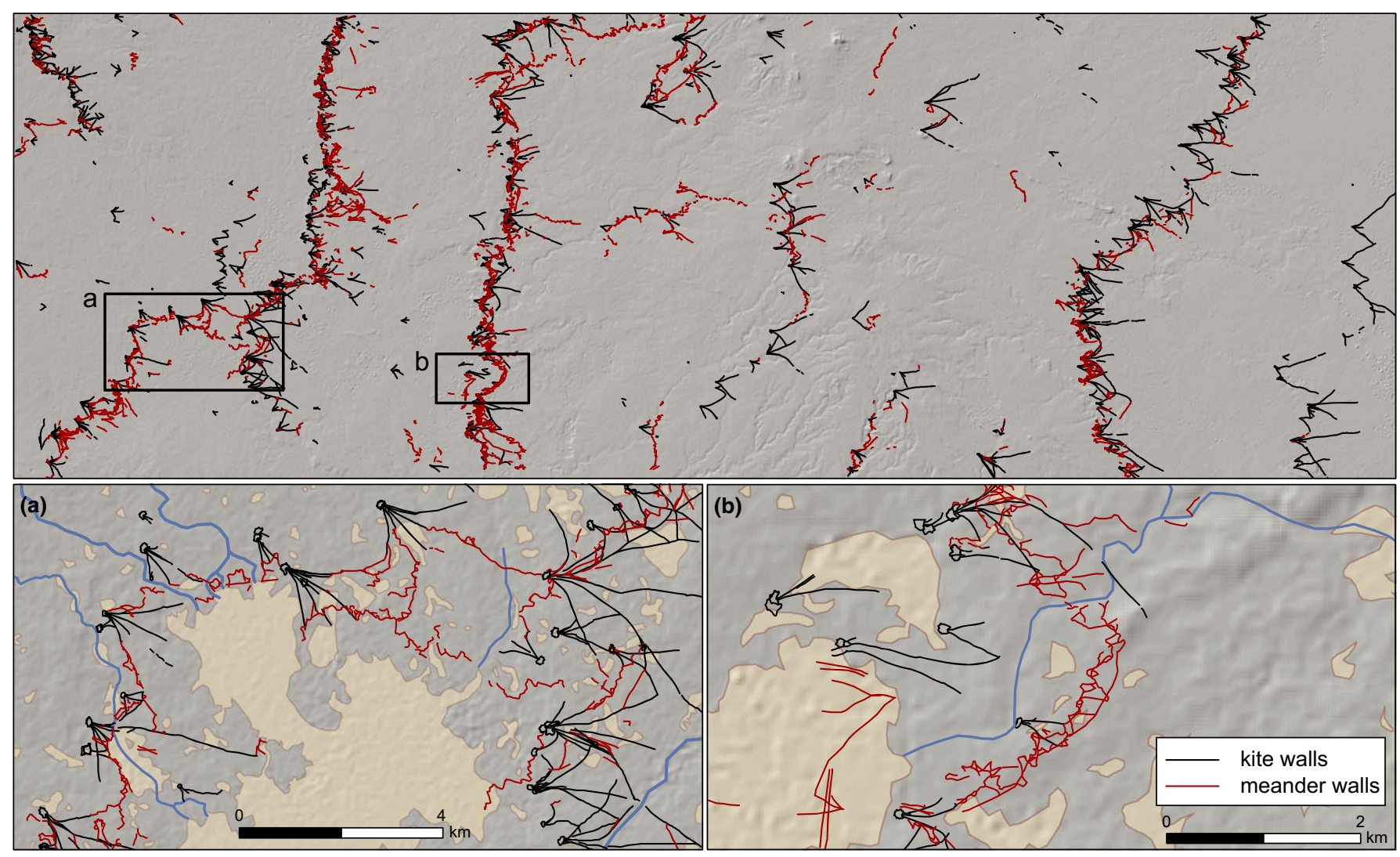

Fig. 8 .

Kites and meander walls: structures that seem to be working together.

tion, this frequency is unique and specific to the Harrat al-Shaam region. It probably reflects a use of kites in the longue durée. Helms and Betts (1987) have suggested that the use of kites could have begun before the Pre-Pottery Neolithic. On the other hand, Akkermans, Huigens and Brüning (2014) consider that all clues for a relative chronology point to kites as the region's most ancient buildings, which would make them of Neolithic age. Whatever the case, some indications of different sorts are perceptible on satellite images:

_ rearrangements within a same kite;

_ superimpositions revealing the temporal succession of several kites;

_ other installations (encampments, pastoral enclosures, 'jellyfish' structures, etc.), which were superimposed on kites;

_ the presence of abandoned projects of kite constructions; the relative position within the same chain.

This last indication is perhaps the most promising one. Indeed, it seems that some of the neighbouring structures could not have been operational simultaneously. Pictures suggest mutual incompatibilities, yet this alone does not allow for an indisputable order of succession, something that exploration and expertise in the field will clarify. The study of satellite images will facilitate the selection of locations, the chronology of which is most likely to be clarified by fieldwork, which will also aim to obtain radiometric dates.

\section{Comparing Jordanian kites to those of Armenia and the Aralo-Caspian region}

Data from the Harrat al-Shaam window in eastern Jordan should therefore be compared to those of two other windows: the Aragats region (in Armenia) and the Ustyurt Plateau of Kazakhstan. These two windows were studied following the same criteria as those of Jordan, even though fieldwork in both Armenia and Kazakhstan made it possible to obtain more detailed data than the results from an examination of the Harrat al-Shaam, which were based primarily on observations of satellite imagery. 


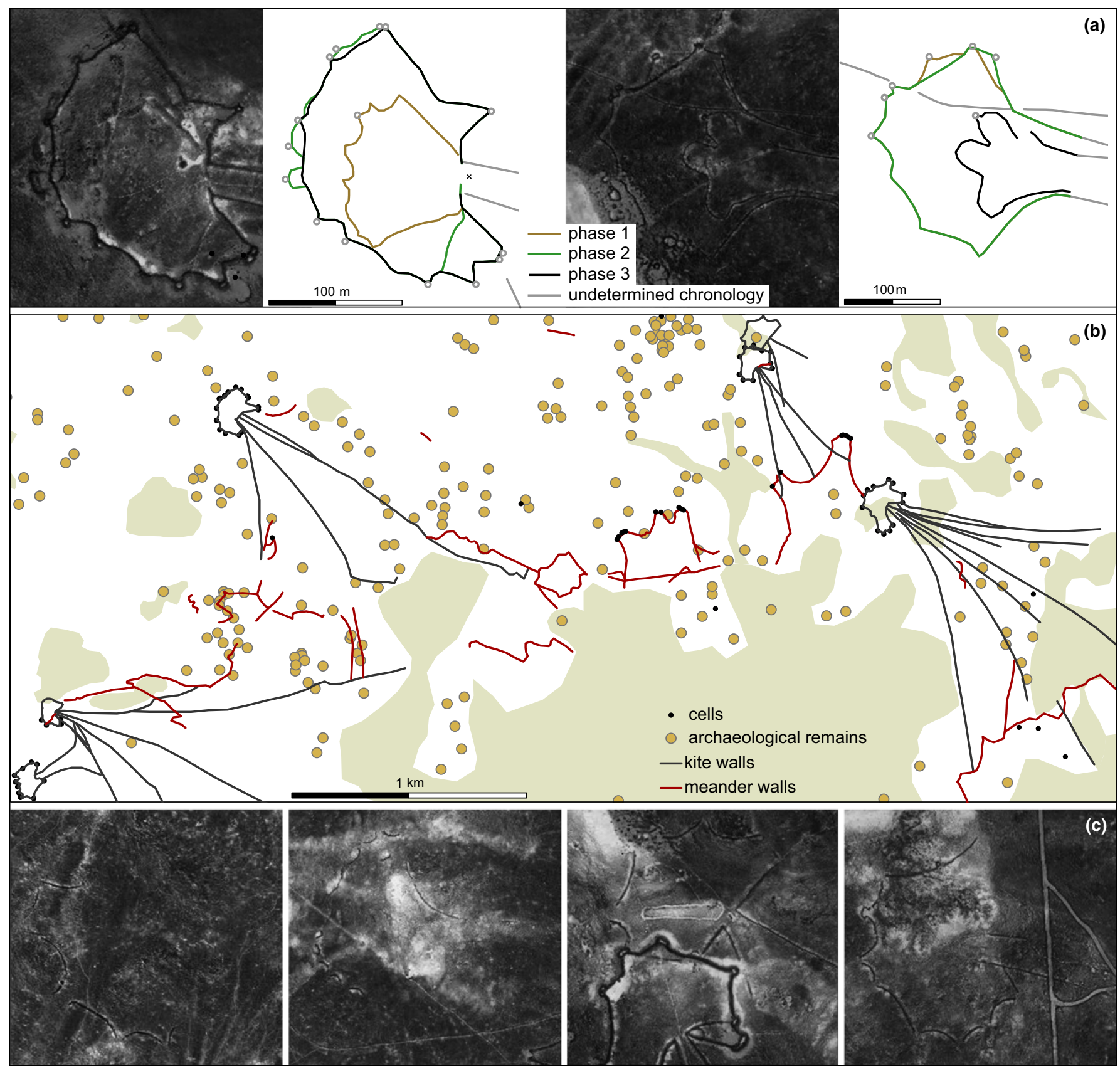

Fig. 9.

Clues for the relative chronology of kites observed on satellite images: a. the cases for superimposition, with up to three states interpreted; b. archaeological remains surrounding the kites. The dots position the remains without reflecting their nature and their scope. Black dots locate the cells, associated to kites or to meander walls; c. unfinished kites at different stages, imagining the stages of kite construction.

Main observations concerning Armenia's kites and those of the Aralo-Caspian region

In Armenia, the Aragats kites form an isolate totalling 179 kites over a surface of a little above $100 \mathrm{~km}^{2}$ (Brochier et al. 2014). They are strung along the edges of lava flows: the entrance is generally built on a break in the slope marking the front of the flow. The antennae face uphill and the enclosure runs downhill. The enclosure, roughly circular or triangular in shape, includes pointed cells which, when they are numerous, alter the kite form to 
make it similar to a star. The entrance is often funnelshaped (51\% of the cases) and proximal cells are frequent ( $80 \%$ of kites have at least one proximal cell). The cells, either circular or forming a quadrangle, are completely closed and their floor is lower than the enclosure's. Extensive morphological homogeneity can be noted within this entire set, and there are very few signs of alterations. Their use, of unknown duration, is today placed between the beginning of the Bronze Age and the beginning of the Iron Age.

The vast Ustyurt Plateau located between the Caspian and the Aral seas is covered with 508 kites (Barge et al., in press). One can immediately distinguish two very different types of kites. On the one hand, there are very large and very original kites, which show a subdivision of the enclosure in the shape of an arrow, on each side of the entrance (arrow-shaped structure: Yagodin 1998). These kites are located within the plateau's interior, where they are organised in chains. On the other, some kites are located along the cliff that marks the edge of the plateau, locally called the 'Chink'. One can subdivide them into three sub-types, as a consequence of the part played by the Chink in their construction. The latter is impassable and often replaces the enclosure wall, at least in part. For the same reason, the Chink is often used as an antenna, explaining the fact that kites in this part of the Ustyurt often have less than two constructed antennae. The Chink is then cleverly used in the kite's plan to make it functional while minimising the energy necessary for its construction. Without going into the details that distinguish these kites from one another, they all have in common a funnelshaped entrance, bordered on both sides by a proximal pointed cell. The cells are circular and closed and their floor surface is lower than that of the enclosure. Cases of superimpositions of kites belonging to several generations were noticed, more in the field than from satellite pictures. The period of use is therefore probably quite long and seems to end as late as the eighteenth century $\mathrm{AD}$, according to our ${ }^{14} \mathrm{C}$ dates (Barge, Brochier \& Karakhanyan 2015).

Only the kites located on the plateau's edge, near the south-western Chink, were systematically recorded in terms of their characteristic features, and will be compared to those of Armenia and the Harrat alShaam. Some features were nevertheless noted in the case of the plateau's kites with double arrows (location, orientation). When available, they will themselves be the subject of comparisons relating to these very characteristic features.
Table 1. Parameters for the relative location of kites in the four sets compared.

\begin{tabular}{|c|c|c|c|c|}
\hline & Armenia & $\begin{array}{l}\text { Ustyurt } \\
\text { Chink }\end{array}$ & $\begin{array}{l}\text { Ustyurt } \\
\text { Plateau }\end{array}$ & $\begin{array}{l}\text { Harrat } \\
\text { al-Shaam }\end{array}$ \\
\hline Density $\left(k i t e / \mathrm{km}^{2}\right)$ & 15.4 & 6.6 & 0.2 & 14.2 \\
\hline $\begin{array}{l}\text { Average distance with } \\
\text { the closest neighbour (m) }\end{array}$ & 898 & 1018 & 4537 & 711 \\
\hline $\begin{array}{l}\text { Relative standard deviation } \\
\text { of the distance with the } \\
\text { closest neighbour (\%) }\end{array}$ & 95 & 254 & 140 & 110 \\
\hline In contact $(\%)$ & 23.5 & 2.9 & $\begin{array}{l}\text { Not } \\
\text { available }\end{array}$ & 35.4 \\
\hline
\end{tabular}

\section{Regional importance of the kite phenomenon}

To begin with, we shall attempt to assess the scope of the presence of kites within the three windows, to which we shall add the fourth set corresponding to the double arrows in the Ustyurt Plateau's interior. Two variables can be calculated: density - the number of kites per surface unitand the distance of each kite from its closest neighbour (Table 1 and Fig. 10).

Density is the ratio between the number of kites and the surfaces on which they are found. To delimit this surface the least arbitrary method consists in defining a convex hull encompassing all the kites considered in each of the windows. The results yield very high values for Armenia and for the Harrat al-Shaam. Density, which remains important, is twice as low for kites along the Ustyurt's Chink, while it is very low for the kites within the plateau itself. The value of the considered surface very much depends on the manner in which kites are distributed and only one off-centred item is necessary to alter this value in a considerable way. One cannot therefore reasonably interpret disparities between values of similar density. Despite this limitation, this calculation allows one to say that densities are very high in the Harrat al-Shaam and Armenia, medium along the Ustyurt Chink and very low in the plateau's interior.

The mean distance to the closest kite tends to confirm previous data. Very high for the double-arrow kites of the Ustyurt Plateau, they can be distinguished very clearly from the three other sets of data. Of low density and subjected to important inter-kite distance, these kites cover only a small proportion of the total surface of the plateau. By contrast, inter-kite distances in other windows are rather small, with values being inferior or close to $1 \mathrm{~km}$; the presence of kites is then massive. This datum would tend, therefore, to connect the Harrat al-Shaam kites to those of Armenia and the Ustyurt Plateau's edge. The relative standard deviation of the dis- 


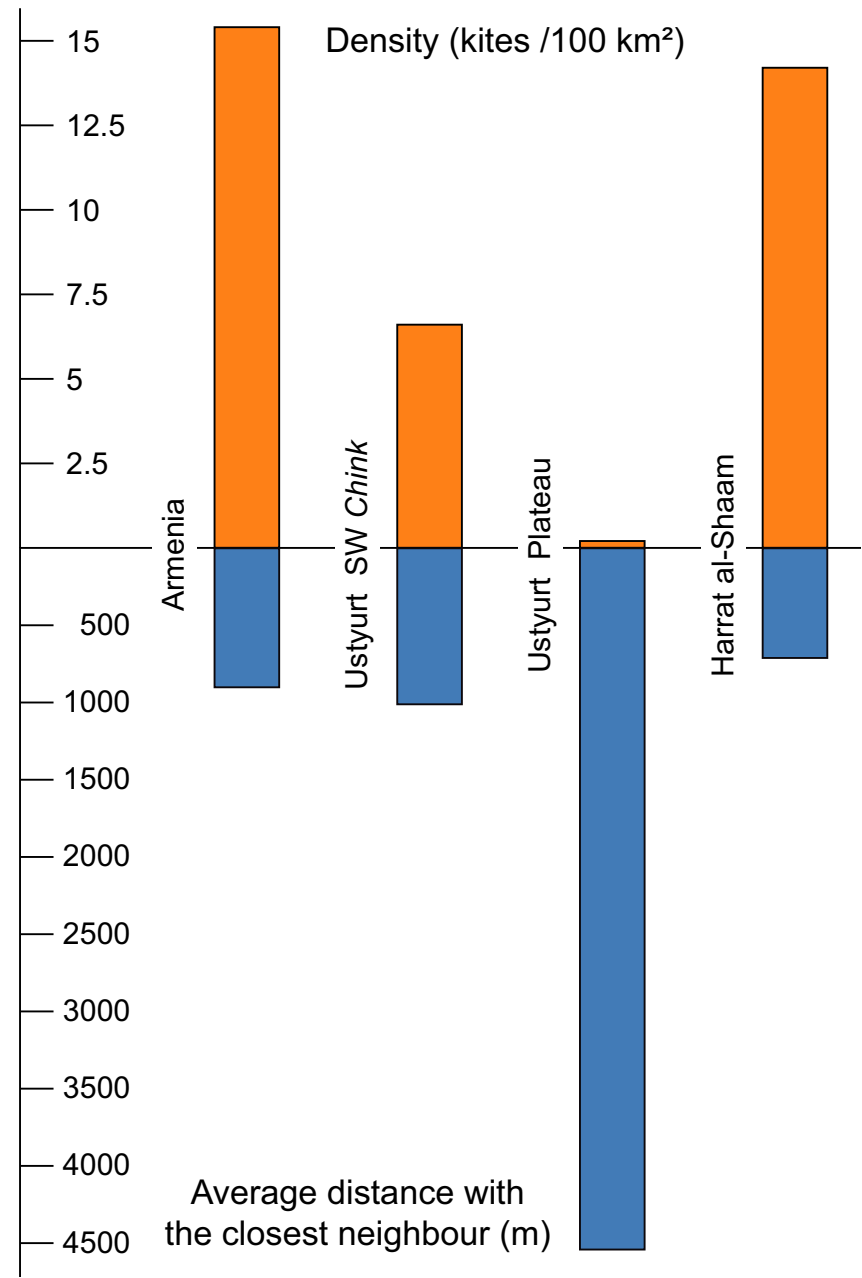

Fig. 10

The density of kites and the inter-kite distance.

tance with the closest neighbouring kite, however, is twice as large in the Ustyurt's Chink than in Armenia or the Harrat al-Shaam (Table 1). This reflects the fact that, in this case, some kites are close to one another, while there are others that are isolated. Furthermore, while the kites of the Ustyurt Plateau's edge are individually functioning units, in Armenia one kite in four is in contact with a neighbour. In the Harrat al-Shaam, this proportion reaches one in three. In this region, kites are clearly organised in chains.

\section{Clues to the evolution of the kite phenomenon}

The observation of changes in a kite's plan, as well as the distinction between superimposed individual stages, are clues revealing the evolution in the use of kites. They are very infrequent in Armenia, a point leading to the conclusion of a very circumscribed and short use over time
Table 2. Clues to the evolution in the use of kites: changes in plan superimposition of kites of different generations.

\begin{tabular}{|llll|}
\hline & Armenia & $\begin{array}{l}\text { Ustyurt Chink } \\
\text { (Kazakhstan) }\end{array}$ & $\begin{array}{l}\text { Harrat al-Shaam } \\
\text { (Jordan) }\end{array}$ \\
\hline Total number of kites & 179 & 508 & 530 \\
Modifications (\%) & 9.5 & 15.7 & 44.8 \\
Superimpositions (\%) & 1.1 & 25.8 & 45.5 \\
\hline
\end{tabular}

(Table 2). These clues are more numerous on the Ustyurt Plateau's edge, while field exploration has demonstrated that superimpositions are not all observable on satellite images. By contrast, one can distinguish them in great detail in the Harrat al-Shaam, and their presence is very frequent: only $36 \%$ of kites show neither superimposition nor modification. The kite phenomenon thus seems to be long in duration, even though this perhaps also reveals modifications in the way kites were exploited; the scope and complexity of these rearrangements, which are not only successive additions, leads to the possibility of evolutions, either in the way kites operated, or in the sharing of territory in which they were used or even in the animal species concerned. Despite the apparent complexity of these modifications, it is not impossible to discern a chronological trend, which could yield a wealth of chronological and functional information.

\section{Locations in the landscape}

When restricting the study to the three windows and to the set of kites from the interior of the Ustyurt Plateau, it appears that the way a kite is placed in the landscape could derive from two broad organisational forms. In the first, a general organisation in chains groups kites with an orientation that is perpendicular to the chain; in the second form, the kite's orientation and positioning are dictated by topography.

In the case of the Ustyurt Plateau's interior, the doublearrowed large kites are essentially organised in chains, even though one also encounters isolated kites, such as those noted in the Harrat al-Shaam. Despite some exceptional examples of inverse orientation, each kite points in the same north direction and is perpendicular to the alignment of kites in the chain. Even though the disposal of kites in relation to others is less regular and more complex, the Harrat al-Shaam shows analogous organisation, since the great majority of kites open towards the east. In both cases, some kind of large-scale barrier is erected, without necessarily making use of the topography (although $85 \%$ of kites in the Harrat al-Shaam window reveal a break in the slope at the enclosure's entrance). 
In the case of Armenia, the front of lava flows determines the kite's position and orientation. A peculiar topographical configuration in the landscape was therefore sought by the kite builders. From this perspective, the situation is comparable in the south-western edge of the Ustyurt Plateau. The Chink, a cliff bordering the plateau edge and a major topographical landmark, was selected to place a kite; in many cases, it was even included in the kite's plan and acted as a wall. The general principle is the same: local topography presents opportunities that are deliberately sought by the builders, something that determined the location and orientation of the kites.

In Armenia kites are most often placed on the front of volcanic flows ( $78 \%$ of the cases), and are sometimes regularly spaced (about one out of two). The antennae, however, are generally not connected with those of the neighbouring kite, and there are many instances where these linear distributions do not appear. In any case, dominant orientations can be observed (south-east quadrant), but one cannot know if they are the result of deliberate choice or the consequence of the general direction of lava flows.

The orientation of kites was often interpreted according to the migration routes of animals (Legge \& RowleyConwy 1987; Helms \& Betts 1987; Martin 2000; Zeder et al. 2013; Chahoud et al. 2015; Chahoud, Vila \& Crassard, this volume 2015). This interpretation seems logical in the case of the Ustyurt plateau, where the migration of the Saiga antelope, attested and oriented towards meridians (from the north to the south in autumn; e.g. Bannikov 1958; Bekenov, Gravechand \& Milner-Gulland 1998; Singh et al. 2010), coincides with the orientation of double-arrowed kites (Yagodin 1998; Betts \& Yagodin 2000; Barge et al., in press). In the Harrat al-Shaam, where the criterion of kite orientation is also fundamental, there is no evidence at our disposal of animal migration related to this pattern (for a review of what is known on migrations of wild ungulates in the Near East, see Martin 2000; Gourichon \& Helmer 2008; Chahoud, Vila \& Crassard, this volume 2015). Elsewhere, when kites are not organised in chains, this is merely an explanation among many other plausible ones.

\section{Morphology}

According to our definition, the kite comprises antennae, the enclosure and cells (Barge, Brochier \& Crassard, this volume 2015). From the inventory of characteristic features of kites belonging to the three windows studied, it is possible to make comparisons concerning the length
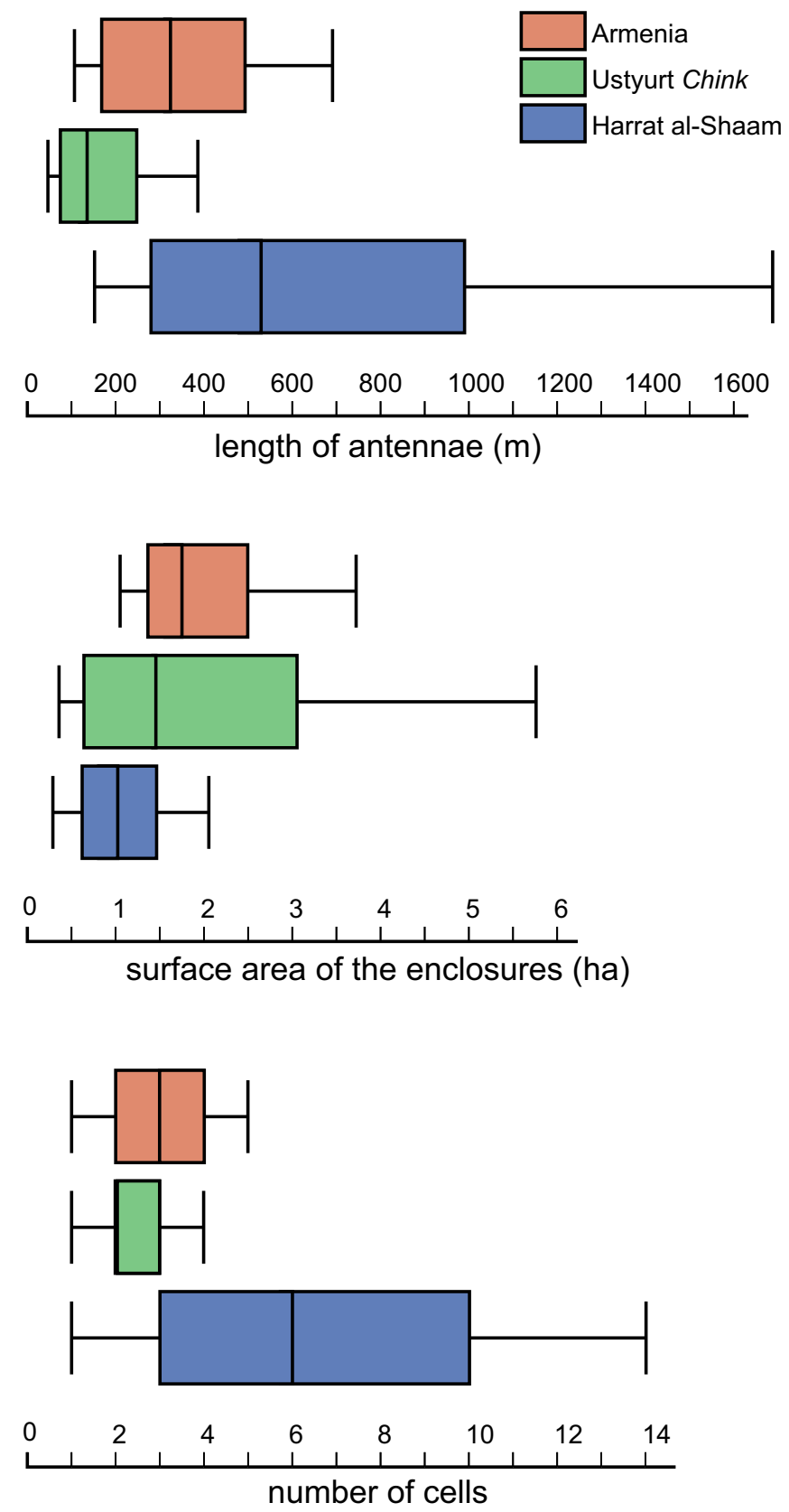

Fig. 11.

Top: box-plots of the length of the antennae; centre: the surface of the enclosures; bottom: the number of cells. The whiskers show the first and ninth deciles.

of antennae, the enclosure's surface and the number of cells.

The antennae are always very short along the Chink in Kazakhstan, but they can be of larger scope in Armenia, yet without reaching the considerable lengths often noticed in the Harrat al-Shaam (Fig. 11/a). If antennae 


\section{UNITY AND DIVERSITY OF THE KITE PHENOMENON}

rarely reach more than $200 \mathrm{~m}$ along the Chink, however, there is more diversity in Armenia, where some kites show very short antennae and others have more developed ones. The spread of antennae lengths is even greater in the Harrat al-Shaam, where antennae several kilometres long are attested concomitantly with quite short ones. In the Harrat al-Shaam, it is also quite frequent that the number of antennae is higher than the usual standard of two antennae (46\% of the cases). This has been noted in Armenia (6\% of the cases), while along the Chink many kites possess only one antenna, or none at all; in the latter case the edge of the cliff fulfilled the function of the antenna.

As regards the enclosure surfaces (Fig. 11/b), it was noted that those of Armenia and the Harrat al-Shaam are relatively not very variable, those in Armenia being substantially larger than the Jordanian ones ( $75 \%$ of the total measure more than 1.5 ha in Armenia, while in Jordan $75 \%$ of the total is inferior to $1.5 \mathrm{ha}$ ). Along the Chink, the presence of many rock spurs makes comparisons difficult; these kites that cleverly make use of the cliff edge revealed an entrance built at the spur's narrowest point. The surface defined by the spur behind the entrance is therefore as variable as the diverse natural configurations, which at times outline either huge or, on the contrary, tiny enclosures.

The number of cells (Fig. 11/c), low in Armenia-and even more so along the Chink-stands in stark contrast to the Harrat al-Shaam where, while kites can show very varied configurations with a few or many cells, their number is generally higher.

The existence of morphological traits common to both the Armenian kites of the Aragats and those of the Ustyurt Plateau's edge has been highlighted (Barge, Brochier \& Karakhanyan 2015). These kites share a tendency for few cells (Armenia, interquartile range (IQR) [2-4] and Ustyurt, [2-3]), the latter most often 'pointed' ( $73 \%$ of the cells are 'pointed' in the case of Armenia, 94\% in the case of Ustyurt). The entrance is very frequently funnel-shaped, positioned between two proximal and 'pointed' cells. As for the two characteristic features ('length of antennae' and 'number of cells'), these two regions are relatively similar to one another when compared to the very different Harrat al-Shaam. In the latter, there are very few funnelshaped entrances. This tendency could not be verified in relation to the surfaces of enclosures, due to the specifics mentioned for kites on the edge of the Ustyurt.

Despite the observable similarities, a general assessment is of the multiplicity of cases. Even limiting comparisons to three characteristic features reveals a great inter-regional diversity. They were nevertheless quite uniform when studied on a regional scale, so that the discovery of regional groups was possible (Barge, Brochier \& Crassard, this volume 2015).

\section{Cell building methods}

In the case of the Ustyurt and Aragats, places where kites were studied in detail in the field and where a significant number of cells were excavated, it was surprising to find common features in the architecture for areas so far from each other. Along the Chink, cells are somewhat circular, sometimes linearly truncated by the wall separating them from the enclosure. Their average diameter is $4.5 \mathrm{~m}$. The Aragats cells show the same average dimension when they are circular, and are a little larger when they are quadrangular (4.5 x $6.5 \mathrm{~m}$ on average). Despite a geological substratum yielding very different construction materials (irregular basalt blocks, with blunted edges in Armenia, limestone slabs whose calibrated thickness allowed for the carving of quite regular rubble in the Chink's vicinity), several architectural details follow the same principle in both regions:

— the cell's floor is always at a lower elevation than that of the enclosure. This difference in height can vary, but is generally approximately $1 \mathrm{~m}$. Two ways of obtaining this difference in level were distinguished in Armenia: either the cell was dug in the substratum or bedrock, or a break in the slope was used (at the point where cell and enclosure are in contact), so that the cell's floor was downhill. The two occurrences along the Chink were noticed, even if the use of a break in the slope is less frequent;

the cell is always found in the external part of the enclosure;

the cell seems to be completely closed on the side of the enclosure. The walls that constitute this cell are not of significantly different elevation. The wall common to the cell and the enclosure clearly delimits it. Ustyurt's kites are also characterised by internal ramps in cells, suggesting an important (functional) difference;

when preservation is good enough for such observation, the upper stone courses are slightly shifted, defining a slight overhang towards the interior;

in the Harrat al-Shaam, to the best of our knowledge it would seem that certain features can also be confirmed with certainty: the cells appear 
closed and their floor can be lower than that of the enclosure. This initial observation-added to the examination of satellite pictures - demonstrates above all that cell size and shape showed greater diversity. Some, in the shape of an extended rectangle (with the longer side adjacent to the enclosure), appear to be of considerable dimensions, while there are also 'minicells' of only a few square metres. This diversity could have functional purposes.

\section{Discussion}

From these comparisons and thanks to the new evidence provided by recent work, what is proposed here is a review of the important issues posited by the enigmatic constructions called 'kites'.

\section{Hypotheses on function and the manner in which kites operated}

Soundings carried out in Armenia and Kazakhstan have yielded no artefacts which might suggest what function kites fulfilled, nor have they provided animal bones pointing to the species of animals concerned, which would have enabled scholars to choose without any ambiguity between a hunting hypothesis and a pastoral one. Consequently, one must turn to observations on the position of kites in the landscape, on their morphology or on architectural details, and attempt to interpret them in terms of function. One would have hoped, thanks to conjectural evidence, to lean towards conclusions on a given functional mode and then to progress in the understanding of these functions. Unfortunately, it is necessary to emphasise that these interpretations are often equivocal. Insertion within the landscape does not obey a unique set of rules, since one can distinguish at least two modes, ones structured by chains oriented in a given direction, the other commanded by elements of topography. The analysis of the morphological data shows a constant coexistence of the system of antennae/enclosure/cells, confirming the unity of the kite phenomenon. It also shows a great variability in sizes and shapes, however, without knowing if it is due to regional specificities, to an adaptation to animal species or to evolutions over time.

Nor does the study of architectural details provide clear answers. The care and energy given to the building of the cells - seen in Armenia, on the Ustyurt and in the Jordanian Harrat al-Shaam - make them architecturally the most elaborate element. Always present, these must be indispensable to the kite's proper operation, but since they are apparently completely closed, no hypothesis on function seems irrefutable. The role of cells as places from which to watch prey is not very likely, since this would have required neither such an elaborate construction, nor the closure of the cells on their external side, nor the cell's floor being set below the enclosure's surface. Moreover, as regards the latter, cells appear not very numerous and badly distributed to play such a part. The role of the pit, which animals would have fallen into, is consistent with the difference in level between the enclosure and that of the cells. Nevertheless, how the animals would have entered it (since the separation wall between the cell and the enclosure is, especially in the case of Armenia, as high as that of the kite's enclosure) is poorly understood. The other hypothesis on function - selective stabling of animals or domestic use - faces the problem that cells do not have an opening. In addition, the presence of animals and/or people would have been, in all likelihood, detected during excavation.

Ultimately, very few elements remain that clearly point to a use for hunting. The coherence of distribution and orientation of kite chains with known migration routes of Saiga antelopes in the Ustyurt Plateau's interior is, for this family of kites, the most convincing element. In the Jordanian case, which also shows oriented chains - and even in the other cases - the existence of an axis of seasonal migration for one species is a possible explanation, but there is too little zoological data to support this interpretation (Chahoud, Vila \& Crassard, this volume 2015). The break in the slope at entrance level, which is meant to hide the existence of the enclosure from the animals, is the second element that points towards a use of the kite for hunting purposes. Yet, although this is something that is often noted, it is not systematic.

In the case of enclosures that appear of too large a size, a use of kites for pastoral purposes combined with a lack of explanation for the function of the cells seems less plausible, even though no element allows us completely to dismiss this idea. In the Jordanian case, the presence of several types of very different cells as well as an apparently long duration of the kite phenomenon, raises the question of a possible progressive change in use(s) with time.

The fact is that, in the present state of knowledge, there are too few elements at our disposal to enable us securely and precisely to describe how a kite operated, information without which it is difficult to establish its function.

\section{The kite phenomenon and its chronology}

From a chronological viewpoint, and with the little information available, the data should be carefully selected. If 
UNITY AND DIVERSITY OF THE KITE PHENOMENON

not employing a specialised and systematic counting method both inside and outside the kites - a cumbersome method and without any guarantee of definitive results - it is preferable not to take into account artefacts found on the surface, the latter simply showing a long-term occupation of the surroundings without a proven relationship to the kite itself. Likewise, the presence of petroglyphs (mostly animal representations), the chronology of which is always very approximate, is of little assistance unless they represent kites themselves or kite-related activities. The presence of chronologically reliable elements in the stratigraphy appears to be the only source of data enabling us to date the building and/or use of a kite with certainty. The superimposition of other constructions can help with the establishment of a relative chronology, while the superimposition of several kites is a clue to their long use.

A recent study (Zeder et al. 2013: table 1) shows that knowledge on the matter remains scant. One can observe that more than half of the dated constructions correspond to those encountered in the Negev. The latter are of very small size, do not possess any cells, are relatively few in number and are restricted to this region. Even if they share the principle of converging walls, they are sufficiently distinct from kites with large enclosures and cells to render unlikely any chronological conclusions applied to the latter from the former. Remaining data or chronological clues are then very sparse and, given the geographical area considered and the probable long duration of the kite phenomenon, do not help in refining the chronological and cultural context.

New chronological data concerning the Armenian kites place their use between the beginning of the Early Bronze Age and the inception of the Iron Age. This time frame is still quite wide, even though kite use in Armenia, as regards the extensive morphological homogeneous character and the almost complete absence of superimposition or indication of repair, appears of relatively short duration. On the south-western edge of the Ustyurt Plateau, there are traces of alterations and quite numerous examples of superimposition of kites, which is a sign of use over a long period; this seems to have ended only very recently. In the centre of the plateau, one stereotyped double-arrow kite yielded a terminus ante quem of the Iron Age, without more accuracy (beginning and duration of use).

These recent chronological data, even if of low temporal resolution, show very different inter-regional results and emphasise how rash it is to make generalisations on chronological matters from few examples. Knowledge of the chronology of the kite phenomenon is therefore in its early stages. Each new result, which has to be considered in its geographical context, is an additional benchmark for the kites' long history.

\section{Communities involved and the socio-economic aspect of the kite phenomenon}

The cultural aspect related to the kite phenomenon is still very poorly understood, including social organisation and economical aims and the impact of the kites' builders. It must be said that interest for this topic is relatively recent. When faced with the scope of the issues remaining it seems quite appropriate to open the field of questioning further. This is a new field of research, for which one can bear in mind several questions containing promising developments: how was the organisation of the territory of the kite builders? What was the place of the kite inside this territory? What relationship can one detect between the social organisation of the relevant groups and collective practices involved by the use of kites? The impressive quantity of kites suggests widespread economic activity. What were the consequences of this economic activity and can one detect its traces?

\section{Extension, dispersal and distribution patterns}

If answers brought to the above-mentioned questions seem unsatisfactory, the question of geographical distribution has, in the last four or five years, seen important advances. The increasingly complete coverage of the Near East by easily accessible high-resolution satellite images (Google Earth, Microsoft Bing), enabling clearly to identify and outline kites, has radically modified our knowledge of the phenomenon. The scale of magnitude has changed: a little while ago, the total number of specimens was estimated to be in the hundreds. Today, according to the most recent inventory, the number exceeds 5000 individual structures. It is now known that if the Harrat al-Shaam basalt region appeared as a large area with very great density, there are other zones, albeit less extensive, which have revealed comparable density; among those previously described, such as the Palmyrene mountains, others were recently discovered, such as Armenia or Central Arabia. The regions where mention was made of kites saw the completion of their inventory, which was often multiplied many times (the Ustyurt Plateau, the El Kowm region, Jebel al-Has, Qaryateyn, etc.) and their extension could also be precisely traced. New areas of lesser extension and density were also discovered (southern piedmonts of the Taurus in eastern Turkey, Jazira). New kites, or even small isolated concentrations, 
are regularly discovered in regions of low density (southern Jordan, northern Arabia, Ustyurt Plateau). In any event, the general geographical distribution is neither random, nor homogeneous: kites have a tendency to concentrate in large numbers in relatively circumscribed sectors. There are thus vast areas with gaps and areas where the absence of kites cannot be confirmed because some of them are not visible on the satellite images.

The last few years have witnessed a momentous enlargement of the inventory and of the area of extension (Crassard et al. 2014). Even though they are an isolated case, the Armenian kites enable us to link the Aralo-Caspian group with the Near Eastern one. Their existence, as well as the analysis of their characteristic features (the presence of cells in particular), enables this regrouping. One could suggest that the kites, from the Ustyurt Plateau to Central Arabia, all belong to the same phenomenon.

Thus, satellite images not only render possible kite identification but also enable many morphological observations. Recorded in a database storing a representative sample of the area of distribution, it is today possible to propose maps showing that most characteristic features are regionalised (large size of enclosures in the north, important number and lengths of antennae in the south-east of the Harrat al-Shaam, for instance). Early mapping attempts show that it is possible to create homogeneous groupings which can be individualised spatially (Barge, Brochier \& Crassard, this volume 2015); these three groupings, once refined and cross-matched with ever more substantial field data, should enable the reconstruction of a spatial-temporal dynamic of the kite phenomenon.

\section{Conclusion}

Comparisons of kites in three different locations of the global distribution area, be it from the viewpoint of architectural details, general morphology or the way in which they integrate into their environment, show common features that are sufficiently unusual to support the idea that the kites belong to the same phenomenon, despite both an extensive and a very erratic geographical distribution. What can be discerned, however, is a very great diversity, the explanation of which is potentially found in a variety of practices, if not in functions. This variety, moreover, should be conceived with a chronological perspective in mind (duration and dating).

Recent progress was recorded on the issue of kites, and new fields were explored. This work shows that the validity of an observation in one specific location cannot always be applied to all kites. Regional criteria, be they typological or chronological, constitute the matrix of the kite phenomenon. Data is still lacking today. Some of this missing information is crucial, such as explanatory data on the issues of function and operation of the structures. It is by increasing the number of newly explored regions and kites studied and excavated there that this data will perhaps one day be within our grasp.

\section{Acknowledgements}

This research is conducted under the Globalkites ANR project (funded by the Agence Nationale de la Recherche ANR, France (2013-2017, No. ANR-12-JSH3-0004-01, to R. Crassard). We are very grateful to Wael AbuAzizeh, Alison Betts and David Kennedy for feeding data to the general inventory of kites. We thank Julia Daitche for the work provided on the archaeological environment of kites. For the invitation to Jordan in 2013, we wish to thank Wael Abu-Azizeh and Mohammad Tarawneh. We also warmly thank Aktham Abbadi (Department of Antiquities, Amman), who first welcomed us in 2014. We are grateful for the perspective of future cooperation given to us by those mentioned above and other staff in the department.

\section{References}

Abu-Azizeh, W. \& Tarawneh, M.B. this volume 2015. Out of the Harra: Desert kites in Southeastern Jordan. New results from the Southeastern Badia Archaeological Project. Arabian Archaeology and Epigraphy 26/2.

Akkermans, P.M.M.G., Huigens, H.O. \& Brüning, M.L. 2014. A landscape of preservation: late prehistoric settlement and sequence in the Jebel Qurma region, northeastern Jordan. Levant 46/2: 186-205.

Bannikov, A.G. 1958. Distribution géographique actuelle et biologie de la Saïga en Europe. Mammalia 22: 208-225. Barge, O., Brochier, J.É. \& Crassard, R. this volume 2015a. Morphological diversity and regionalisation of kites in the Middle East and Central Asia. Arabian Archaeology and Epigraphy 26/2.
Barge, O., Brochier, J.É. \& Karakhanyan, A. 2015b. Northernmost kites? Quaternary International. doi:10.1016/j.quaint.2015. 03.051 .

Barge, O., Brochier, J.É., Chahoud, J. \& Chataigner, C. et al. 2013. Towards a new approach to the 'kites phenomenon' in the Old World: the GLOBALKITES Project. Antiquity 87/338, Project Gallery. http:// 


\section{UNITY AND DIVERSITY OF THE KITE PHENOMENON}

antiquity.ac.uk/projgall/barge338/

(Accessed 14 January 2015).

Barge, O., Brochier, J.É., Deom, J.-M. \& Sala, R. et al. in press. The 'desert kites' of the Ustyurt plateau. Quaternary International. doi:10.1016/j.quaint.2015.06.010

Bekenov, A.B., Grachevand, A. \& MilnerGulland, E.J. 1998. The ecology and management of the Saiga antelope in Kazakhstan. Mammal Review 28/1: 152.

Benedict, J.B. 2011. Tundra Game Drives: an Arctic-Alpine Comparison. Arctic, Antarctic, and Alpine Research 37/4: 425-434.

Betts, A.V.G. 1982. Prehistoric sites at Qa'a Mejalla, eastern Jordan. Levant 14: 1-34.

Betts, A.V.G. 1998. The Harra and the Hamad: archaeological explorations in the Jordanian basalt desert. Sheffield: Sheffield University Press.

Betts, A.V.G. \& Helms, S. 1986. Rock art in eastern Jordan: kite carvings? Paléorient 12/1: 67-72.

Betts, A. \& Yagodin, V. 2000. A new look at 'Desert Kites'. Pages 31-44 in Stager, L., Greene, J. \& Coogan, M (eds.), The Archaeology of Jordan and beyond. Essays in honour of James Sauer. Winona Lake, IN: Eisenbrauns.

Brink, J.W. 2013. The Barnett site: A stone drive lane communal pronghorn trap on the Alberta Plains, Canada. Quaternary International 297: 24-35.

Brochier, J.É., Barge, O., Karakhanyan, A. \& Kalantarian, I. et al. 2014. Kites on the margins: the Aragats kites in Armenia. Paléorient 40/1: 25-53.

Chahoud, J., Vila, E. \& Crassard, R. this volume 2015a. A zooarchaeological approach in understanding desert kites. Arabian Archaeology and Epigraphy 26/2.

Chahoud, J, Vila, E., Balasescu, A. \& Crassard, R. 2015b. The diversity of Late Pleistocene and Holocene wild ungulates and kite structures in Armenia. Quaternary International. doi: 10.1016/j.quaint.2015.04. 024

Crassard, R., Barge, O., Bichot, C.-E. \& Brochier, J.É. et al. 2014. Addressing the desert kites phenomenon and its global range through a multi-proxy approach.
Journal of Archaeological Method and Theory. doi: 10.1007/s10816-014-9218-7.

Custred, G. 1979. Hunting technologies in Andean culture. Journal de la Société des Américanistes 66: 7-19.

Échallier, J.-C. \& Braemer, F. 1995. Nature et fonction des 'Desert Kites': données et hypothèses nouvelles. Paléorient 21/1: 35-63.

Gourichon, L. \& Helmer, D. 2008. Étude archéozoologique de Mureybet. Pages 115-227 in Ibañez, J.J. (ed.), Le site néolithique de Tell Mureybet (Syrie du Nord), En hommage à Jacques Cauvin. (BAR International Series, 1843). Oxford: Archaeopress.

Helms, S.W. 1981. Jawa, lost city of the Black Desert. New York: Cornell University Press.

Helms, S. \& Betts, A.V.G. 1987. The desert 'kites' of the Badiyat Esh-Sham and north Arabia. Paléorient 13/1: 41-67.

Holzer, A., Avner, U., Porat, N. \& Horwitz, L.K. 2010. Desert kites in the Negev desert and northeast Sinai: their function, chronology and ecology. Journal of Arid Environments 74/7: 806-817.

Ingold, T. 1980. Hunters, Pastoralists and Ranchers. Reindeer economies and their transformations. Cambridge: Cambridge University Press.

Kempe, S. \& Al-Malabeh, A. 2010. Kites and other archaeological structures along the Eastern Rim of the Harrat (Lava Plain) of Jordan; signs of intensive use in prehistoric time; a Google Earth images study. Pages 199-215 in Middleton, G.J. (ed.), Proceedings of the 14th International Symposium on Vulcanospeleology, Undara Volvanic National Park, Queensland, Australia, August 2010. Undara: Organising Group, 14th International Symposium on Vulcanospeleology 2010.

Kempe, S. \& Al-Malabeh, A. 2012. Distribution, sizes, function and heritage importance of the Harrat Al Shaam desert kites: the largest prehistoric stoneworks of mankind? Pages 57-66 in Abstracts and Proceedings of the 15th International Symposium on Vulcanospeleology, Hashemite University, Zarka, Jordan, 15-22 March, 2012.
Kempe, S. \& Al-Malabeh, A. 2013. Desert kites in Jordan and Saudi Arabia: structure, statistics and function, a Google Earth study. Quaternary International 297: 126-146.

Legge, A.J. \& Rowley-Conwy, P.A. 1987. Gazelle killing in Stone Age Syria. Scientific American 255/8: 88-95.

Martin, L.A. 2000. Gazelle (Gazella spp.) behavioural ecology: predicting animal behaviour for prehistoric environments in south-west Asia. Journal of Zoology 250: 13-30.

Nadel, D., Bar-Oz, G., Avner, U., Malkinson, D. \& Boaretto, E. 2013. Ramparts and walls: building techniques of kites in the Negev Highland. Quaternary International 297: 147-154.

Payne-Gallwey, R. 1886. The Book of Duck Decoys. London: J. Van Voorst.

Riemer, H. 2009. Prehistoric trap hunting in the eastern Sahara deserts: A re-evaluation of the game trap structures. Pages 175-188 in Riemer, H., Förster, F., Pöllath, N. \& Herb, M. (eds.), Desert animals in the eastern Sahara: Status, economic significance, and cultural reflection in antiquity. Cologne: Heinrich-BarthInstitut.

Singh, N.J., Grachev, I.A., Bekenov, A.B. \& Milner-Gulland, E.J. 2010. Tracking greenery in central Asia - the migration of the saiga antelope. Diversity and Distributions 16: 663-675.

Storemyr, P. 2011. The ancient stone-built game traps at Gharb Aswan and beyond, Lower Nubia and Upper Egypt. Sahara 22: 15-28.

Yagodin, V.N. 1998. Arrow-shaped structures in the Aralo-Caspian steppe. Pages 207223 in Betts, A.V.G. (ed.), The Harra and the Hamad. Excavations and explorations in Eastern Jordan, vol. 1. Sheffield: Sheffield Academic Press.

Zeder, M.A., Bar-Oz, G., Rufolo, S. \& Hole, F. 2013. New perspectives on the use of kites in mass-kills of Levantine gazelle: a view from northeastern Syria. Quaternary International 297: 110-125. 